\title{
LAND-USE PLANNING FOR SUSTAINABLE URBAN DEVELOPMENT IN AFRICA: A SPATIAL AND MULTI-OBJECTIVE OPTIMIZATION APPROACH
}

\author{
Alex LUBIDA ${ }^{1}$, Mozafar VEYSIPANAH ${ }^{2}$, Petter PILESJO ${ }^{3}$, Ali MANSOURIAN ${ }^{4}$ \\ 1, 2, 34 Lund University, Sweden
}

Received 21 November 2018; accepted 27 November 2018

\begin{abstract}
Land-use planning, which requires finding a balance among different conflicting social, economic and environment factors, is a complex task needed everywhere, including Africa. One example is the city of Zanzibar in Tanzania, which is under special consideration for land-use revision. From one side, the city has high potentials for tourist industry and at the other side there are major challenges with the city structure and poor accessibilities. In order to prepare a proper land-use plan for the city, a variety of influencing conflicting factors needs to be considered and satisfied. This can be regarded as a common problem in many African cities, which are under development. This paper aims to address the problem by proposing and demonstrating the use of Geographical Information System (GIS) and multi-objective optimization for land-use planning, in Zanzibar as a case study. The measures which have been taken by Zanzibar government to address the development challenges through the Zanzibar Strategy for Growth and Reduction of Poverty (ZSGRP) were identified by studying related documents and interviewing experts. Based on these, two objective functions were developed for land-use planning. Optimum base land-use plans were developed and mapped by optimizing the objective functions using the NSGA-II algorithm. The results show that the proposed approach and outputs can considerably facilitate land-use planning in Zanzibar. Similar approaches are highly recommended for other cities in Africa which are under development.
\end{abstract}

Keywords: Multi-Objective Optimization, Land-Use Planning, Non-dominated Sorting Genetic Algorithm-II (NSGA-II), Zanzibar, Africa.

\section{Introduction}

Urban planning is defined as a technical and political process about the use of land within the urban area, and the overall design of the urban environment (Dodman et al., 2013). It takes into account the future urban development and the optimal urban configuration that will result in sustainable development by creating or strengthening the characteristics of the city's economic, social, and cultural environment (UN-Habitat, 2010; Ahmadi \& Toghyani, 2011). As a result, urban planning is one of the dimensions in promoting sustainable development, with the target to achieve sustainability in urban communities.

Urban planning is an important and complicated process in today's urbanizing world. It is important since it determines and influences variables such as quality of life, social interactions, the environment, and the economic characteristics of a city. It is complicated since a variety of social, economic, and environment factors, generally in conflict with each other (Balling et al., 1999), should be considered as input in the planning process while a good balance between them needs to be achieved in the final output plan.

Traditionally, multi-criteria decision-making (MCDM) techniques have been extensively used for urban planning. In these techniques, the influencing factors are weighted by a group of experts and then a weighted average of the factors is used for the planning process. The outcome of such techniques is influenced, and may be biased, by the opinions of the experts, from its early stages. There are also limitations with the number of factors and the level of complexity that MCDM can solve.

A Multi-Objective Optimization (MOO) technique, see e.g. (Coello et al., 2002), can serve as an alternative solution. With this technique, the complexities of urban planning requirements are quantitatively and/or mathematically defined as objective functions and then by concurrent optimization of the functions a set of optimized solutions are determined, which can be used by decisionmakers. A sensible planning solution to a multi-objective optimization problem is to explore a set of solutions, each

*Corresponding author. E-mail: ali.mansourian@nateko.lu.se 
of which satisfies the objectives at an acceptable level without being dominated by any other solution. An optimal set of plans is independent of the relative importance of objectives and are therefore suitable for complex applications such as land-use planning (Balling et al., 1999).

Multi-objective optimization is an integral part of optimization activities in which there is simultaneous consideration of multiple objectives to be solved (Balling et al., 1999; Stewart et al., 2004; Ligmann-Zielinska et al., 2008; Cao et al., 2011; Shifa et al., 2011; Masoomi et al., 2012; Babakan \& Alimohammadi, 2015).

The city of Zanzibar in Tanzania is under special consideration for land-use revision because of its tourism industry that contributes almost 44\% of GDP (Anderson, 2013; Sharpley \& Ussi, 2014) and its unique history of being a World Heritage Site (UNESCO, 2000; Sida, 2004; Azzan \& Ufuzo, 2005; Awadh, 2007; Hall, 2009; Sjöstrand, 2014). However, there are major problems with the current urban structure and land-use types in Zanzibar. There are overcrowding in the informal settlements, with incompatible land-uses nearby each other, and people have poor accessibility to public utilities and social services (Haji et al., 2006; Myers, 2008; Balsem, 2011; Bissell, 2011; Auma, 2012). Zanzibar government has taken various measures to address the development challenges through the Zanzibar Strategy for Growth and Reduction of Poverty (ZSGRP), which is the national development framework for the country's Vision 2020 (RGoZ, 2011). The framework is in line with the Millennium Development Goals (RGoZ, 2007), which are the international commitments and targets.

The aim of this study is to address the mentioned challenges related to land-use revision, using multi-objective optimization technique for land-use planning. It demonstrates how the proposed approach in this paper can facilitate land-use planning not only in Zanzibar, but also in other cities in Africa which are under development.

The paper is organized in four sections as follows. Section 1 presents reviews of related studies, urban planning in Zanzibar, and multi-objective optimization problems and techniques. Section 2 describes the methodology used for defining and solving multi-objective optimization problems for land-use planning in Zanzibar as well as implementation and tests. The results of running the model in a case study area in Zanzibar are described in section 3. Last section includes discussion and conclusions.

\section{Background}

\subsection{Related studies}

MOO has been used in different studies, where finding a balance among influencing factors has been important. Saadatseresht et al. (2009) used a multi-objective evolutionally algorithm and Geographical Information System (GIS) for evacuation planning by considering capacities and shortest distance to safe areas, and the output from this study showed that the spatial Multi-Objective Problem
(MOP) can facilitate the evacuation planning. Neema and Ohgai (2010) used the Genetic Algorithms (GA) based on a multi-objective optimization model to obtain optimum locations for urban parks and open spaces by applying four objective functions based on the Euclidian distances between the facility and the demand points. The model successfully provided optimum locations of required parking areas and open spaces. Cao et al. (2011) used a spatial optimization model, the Non-dominated Sorting Genetic Algorithm (NSGA) and multi-objective land-use optimization problem (NSGA-II-MOLU) with three objectives; minimizing conversion costs, maximize accessibility, and compatibility of land-use types. The results confirmed the usefulness of the model as a planning support tool to optimize land-use types.

Haque and Asami (2011) optimized two objectives which were to maximize land price and to minimize the incompatibility among adjacent land-use types of an area, and solved these using a genetic algorithm. They showed that the algorithm is an effective and computationally easy and efficient tool for land-use planners to use in generating and evaluating feasible land-use plans to facilitate the decision making process. Haque and Asami (2014) used genetic algorithm based optimization models for urban land-use allocation. Also Shaygan et al. (2014) used NSGA-II to optimize land-use allocation. The results showed that the optimization model can find a set of optimal landuse type combinations in accordance with the proposed conditions. Masoumi et al. (2017) developed and used a model based on NSGA-II for land-use allocation. She optimized four objective functions and the results were interesting to decision-makers.

\subsection{Sustainable urban planning in Zanzibar}

Zanzibar is a semi-autonomous part of Tanzania in East Africa, as shown in Figure 1. It is composed of the Zanzibar Archipelago in the Indian Ocean, $40 \mathrm{~km}$ off the coast of the mainland, and consists of numerous small islands and two large ones: Unguja (the main island, referred to informally as Zanzibar) and Pemba. Zanzibar town is the economic, political, and cultural center of the islands, as well as the administrative headquarter of the Revolutionary Government of Zanzibar (RGOZ). Zanzibar's main economic activities are tourism and the production of spices and raffia (Mahmoud, 2013). In terms of tourism, Zanzibar has a mixture of cultures and historical events where many tourists visit annually. Zanzibar retains a rich history integrating indigenous African roots with assorted Indian, Persian, Arab, and European colonial influences into a unique cultural mix (Azzan \& Ufuzo, 2005; Haji et al., 2006). A part of Zanzibar town, known as the Stone town, was declared a World Heritage Site in 2000 (UNESCO, 2000; Sida, 2004; Azzan \& Ufuzo, 2005; Awadh, 2007; Hall, 2009; Sjöstrand, 2014).

Zanzibar government with the help of other stakeholders is currently reviewing its master plans to address planning problems in Zanzibar. The main focus is to create a 


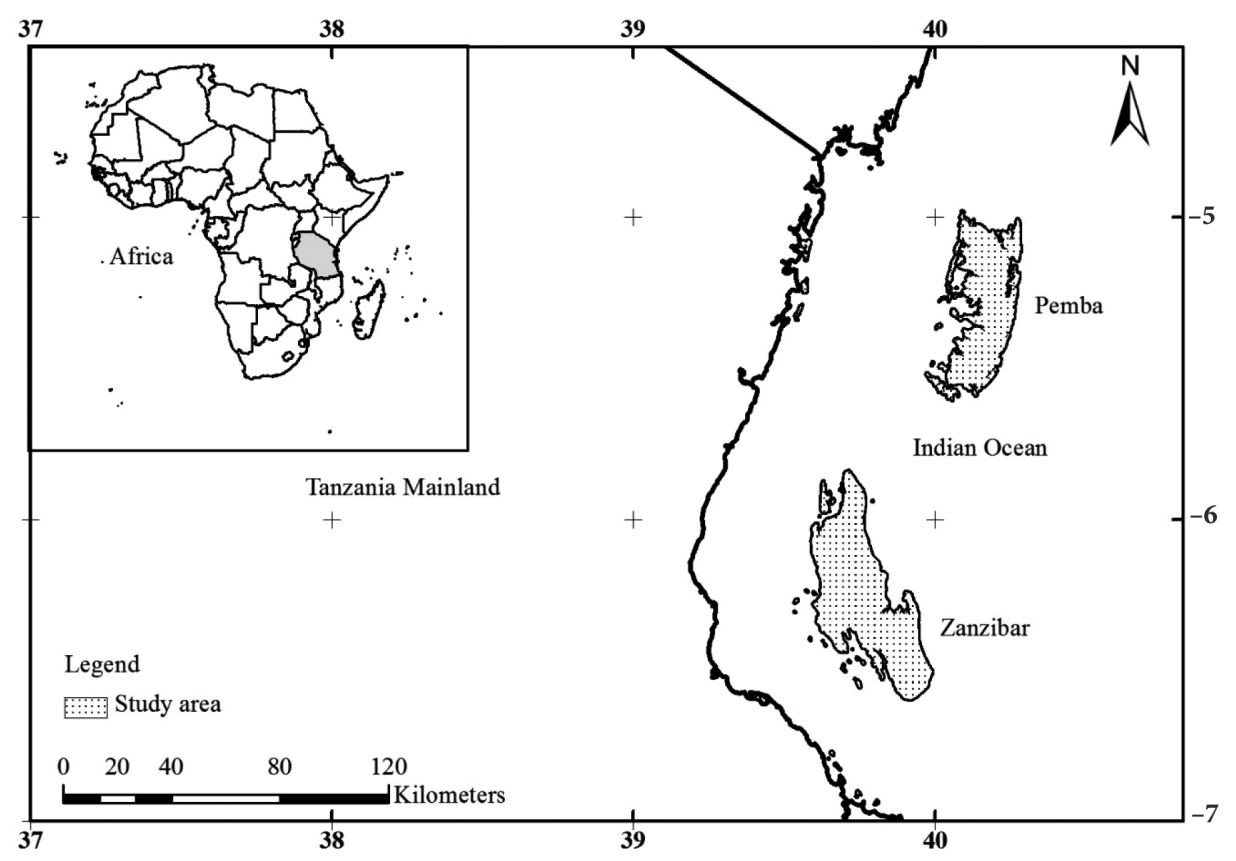

Figure 1. Map showing the study area

sustainable and beautiful city that will attract tourism industry. Currently tourism is the top income generator for the islands, overtaking even the agricultural export industry (Makame \& Boon, 2008; Bissell, 2011; Hikmany, 2012), and the government plays a major role in promoting the industry. According to the Vision 2020 for Zanzibar, the islands are to become one of the top tourism destinations of the Indian Ocean.

\subsection{Multi-objective optimization problem}

The Multi-Objective Optimization Problem (MOOP) is an integral part of optimization activities in which there is simultaneous consideration of multiple objectives in solving optimization problems. It has been applied wherever optimal decisions need to be taken in the presence of tradeoffs between two or more conflicting objectives (Srinivas \& Deb, 1994; Deb, 2001; Datta et al., 2007). The aim of solving a multi-objective optimization problem is to support decision makers when finding the most preferred Pareto optimal solution according to existing subjective preferences. The basic assumption is that one solution of the problem must be identified to be implemented in practice. The multi-objective problem can be represented by the following equation:

$$
\frac{\min }{x \in X^{n_{x}}} f(x)=\left(f_{1}(x), f_{2}(x), \ldots, f_{m}(x)\right),
$$

where $f_{i}(x)$ is the set of $(m)$ objective functions to be minimized and $x$ is the vector of $(n)$ decision variables bounded by decision space $X^{n_{x}}$.

Multi Criteria Decision Making (MCDM) is a wellknown, and still popular, approach for decision-making by considering multiple criteria. It is usually achieved through a weighted sum approach based on a number of alternatives (Ananda \& Herath, 2009; Köksalan et al., 2011; Mansourian et al., 2011; Mosadeghi et al., 2015; Ullah \& Mansourian, 2015). There are a variety of techniques for weighting the criteria such as Technique for Order of Preference by Similarity to Ideal Solution (TOPSIS) (Hwang \& Yoon, 1981) and the Analytic Hierarchy Process (AHP) (Saaty, 1980). Experts' opinions influence the weighting process very much, which may result in bias in making a decision. Pareto optimization is an alternative solution to overcome this issue.

Pareto efficiency or Pareto optimality is a concept in Multi Objective Optimization that allows for the optimization of a vector of multiple objectives, enabling all tradeoffs among optimal combinations of multiple objectives to be evaluated (Fudenberg \& Tirole, 1983; Aguirre et al., 2004). It can be described further as follows; a solution $x_{1}$ is said to be Pareto optimal if there are no solutions better than $\mathrm{x} 1$ with respect to all the objectives. Even if $x_{1}$ is worse than another solution $x_{2}$ with respect to one objective, $x_{1}$ is Pareto optimal provided that it is better that $x_{2}$ in at least one objective. The results from Pareto optimization in most cases are not a single solution, but rather a set of solutions known as the Pareto optimal set. Elements corresponding to the Pareto optimal set are known as non-dominated, and the plot of the objective functions from these elements is called a Pareto front. Optimization is the decision making process intending to get the most out of available resources for the best attainable results (Haque \& Asami, 2011).

A variety of techniques and algorithms have been developed for Pareto optimization, such as swarm intelligence (SI) techniques and evolutionary algorithm based techniques. The most successful methods in SI are the 
Particle Swarm Optimization (PSO), the Ant Colony Optimization (ACO), and the Artificial Bee Colony algorithm (ABC). Among the evolutionary algorithms Genetic Algorithm (GA) is the most popular one.

PSO is a population based technique originating from the simulation of social behaviour of insects and animals, such as the flight of a flock of birds when they search for food and the behaviour of fish schooling (Kennedy \& Eberhart, 1995; Kennedy, 1997; Shi \& Eberhart, 1998). PSO techniques are to some extent related with the evolutionary algorithms, except that the potential solutions or particles move instead of evolving through space. Multiobjective PSO has a drawback in selecting global and local guides that will lead the swarm towards the Pareto optimal front and maintain sufficient diversity (Xu et al., 2015).

$\mathrm{ABC}$ is an optimization algorithm based on the intelligent foraging behaviour of honey bee swarms (Karaboga, 2010). It also provides a population-based search procedure inspired from bee's behaviour for finding food sources. Different approaches and modifications to existing approaches have been proposed to improve multi-objective $\mathrm{ABC}$, such as those proposed by Wang and Li (2015) and Martin-Moreno and Vega-Rodriguez (2018). A drawback of the $\mathrm{ABC}$, in general, is premature convergence in the later search period and the accuracy of the optimal value which cannot always meet the requirements (Yan \& Li, 2011).

Ant Colony Optimization (ACO) is a population paradigm based on the evolutionary mechanics of the foraging behaviour of natural ant colonies (Colomi et al., 1991; Dorigo, 1992). It uses a probabilistic model to solve computational problems where good paths can be obtained through graphs. One of the drawbacks is on estimating the theoretical speed of convergence.

Genetic algorithms are optimization algorithms that uses the evolutionary principles of natural selection and genetics. Several Evolutionary Multi-Objective Optimization methods have been developed. Examples are the Multi-Objective Genetic Algorithm (MOGA) (Fonseca \& Fleming, 1993), the Niched Pareto Genetic Algorithm (NPGA) (Horn et al., 1994), the Random Weighted Genetic Algorithm (RWGA) (Murata \& Ishibuchi, 1995), the Non-dominated Sorting Genetic Algorithm (NSGA) (Deb, 2001), the Strength Pareto Evolutionary Algorithm

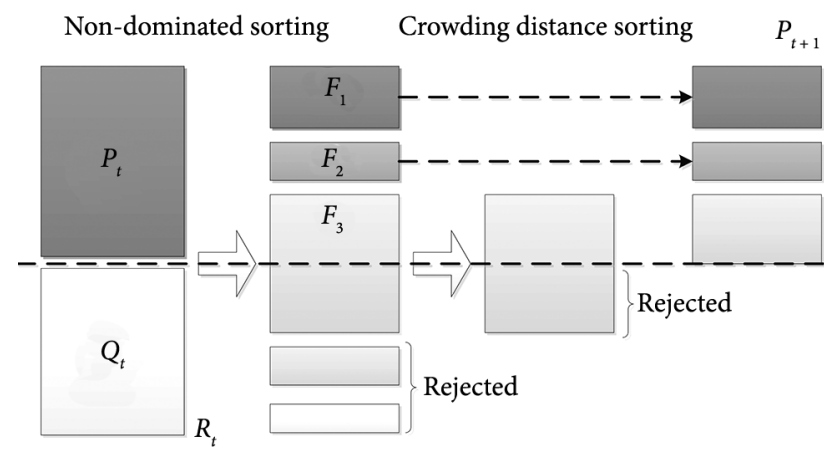

Figure 2. An illustration of the NSGA-II procedure (Deb et al., 2002).
(SPEA) (Zitzler \& Thiele, 1999), and the fast and elitist Non-dominated Sorting Genetic Algorithm (NSGA-II) (Deb et al., 2002). Saadatseresht et al. (2009) have reviewed the techniques briefly.

The Non-dominated Sorting Genetic Algorithm (NSGA-II), developed by Deb et al. (2002), was concluded to be the most appropriate algorithm with advantages over others, for the study presented in this paper. The three main features of NSGA-II include the elitist principle in which a superior set of individuals are chosen, an explicit diversity mechanism, and an emphasis on a non-dominated solution (Deb et al., 2002; Datta et al., 2007; Deb, 2014). In this study, NSGA-II was employed because of its efficiency in searching for alternative optimum solutions with trade-off sets, which results in provision of nondominated plans on the Pareto frontier. Figure 2 illustrates the procedure of the NSGA-II.

The procedure starts with creation of a random parent population $P_{t}$ and offspring population $Q_{t}$, each of size $\mathrm{N}$ which forms a combined population $R_{t}$ of size $2 \mathrm{~N}$. The population $R_{t}$ is sorted in non-dominated fronts where the solution in the first non-dominated front F1 is better than those in the second non-dominated front F2 and so on.

After sorting, non-dominated fronts are added sequentially to a new population $P_{t+1}$, starting from the first ranked front until the size exceeds N. In order for $P_{t+1}$ to remain with population $\mathrm{N}$, lower ranked nondominated solutions are eliminated by using a crowding distance metric sorting. Crowding distance is a parameter that permits to preserve diversity among solutions of the same non-dominated front. The created population $P_{t+1}$ is then used in the binary tournament selection (see Jebari \& Madiafi, 2013), cross-over, and mutation operators, to create a new offspring population $Q_{t+1}$ of size N. After initial generation, and because of elitism in NGSA-II, the new population is compared with the previously found best non-dominated solutions. The process is repeated until the maximum number of generations is reached.

\section{Methodology and implementation}

\subsection{Requirements analysis and data collection}

Data collection was done in Zanzibar to obtain the requirements for the land-use planning optimization. A mixed method approach (Creswell \& Plano Clark, 2007) including direct observations of the current situation of different land-uses, in-depth interviews, group meetings, and document analysis was employed. Apart from the above-mentioned methods, informal interviews were conducted during the entire period of the fieldwork.

Key informants from the government authorities were identified and contacted. Senior officers from three departments: Survey and Mapping, Urban Planning, and Land Registration, which are under the Ministry of Lands, Housing, Water and Energy in Zanzibar, took part in this study. In addition, the municipal engineers from Zanzibar Municipal Council were also involved. 
In terms of interviews open ended questionnaires and discussions were used to capture important information. This approach offered flexibility in emerging new topics and opening more discussion with the experts. Questions focused on the aim and the main objective functions of planning in Zanzibar, and how the objectives are optimized.

Apart from interviews, secondary data such as government reports, policies, plans, maps, and information about land-use types and their distribution percentage, as well as existing and proposed master plans for Zanzibar, were obtained during the field work in Zanzibar. The statistical data were obtained from the National Bureau of Statistics of Tanzania, and included information on social economic variables and population projections. The GIS data for the study area containing various layers including buildings, roads, rivers, boundaries, and height contours were obtained from the Sustainable Management of Land and Environments (SMOLE) project. The data were verified and updated using up-to-date topographical maps and Google earth software.

From the surveys and interviews it was realized that the development plan in Zanzibar aims at accelerating social and economic growth, tourism attraction, and preserve environmental, historical, and cultural heritage. It also draws a framework to support sustainable land management. This can be done specifically by providing appropriate utilities, services, and amenities to all inhabitants, and by preserving Zanzibar's unique culture and heritage.
Proper mix of land-uses including considering the proximity of related land-uses was a demand for urban development. In addition, tourist attraction was a focus for the development of the city, seeking for more hotels and recreational areas at suitable places. Improving accessibility by decreasing the travel distances between the residential areas and the basic facilities such as schools/ universities, green areas, and health care centres was also a requirement.

\subsection{Data preparation}

A study area of four by four kilometres in Zanzibar town, surrounded by Mombasa road on the east side and the ocean on the west, was selected. Then a land-use map of the study area was prepared. The land-use types were modified and re-categorized based on the requirement analysis and previous studies by Khatib et al. (2004), Forson (2011), and Auma (2012) as shown in Figure 3. The percentages of the land-use areas that should be satisfied in the plan were determined based on Zanzibar development plans and interviews. The available and the needed areas in percentages are presented in Table 1 below.

Using GIS, the raster map with a resolution (cell size) of 100 meters was created from the land-use map (Figure 3). The raster map was further used for creating a constraint map as illustrated in Section 3.3. The resolution selected is based on the minimum cell size required to be assigned to land-use types such as schools, shopping

Table 1. Main land-use types in the study area, with existing and planned coverage

\begin{tabular}{|c|c|c|c|c|c|}
\hline Land-use types & Description & $\begin{array}{l}\text { Existing } \\
\text { area }\end{array}$ & $\begin{array}{c}\text { Planned } \\
\text { areas } \\
(\%)\end{array}$ & $\begin{array}{c}\text { Areas/ } \\
\text { cells }^{*} \\
\text { needed }\end{array}$ & Condition / Recommendation \\
\hline Residential & & 0 & 52.6 & 770 & Mixed with other LU \\
\hline Schools & & 17 & 2.4 & 18 & Best less than $600 \mathrm{~m}$ away for children \\
\hline Higher education & University and art schools & 1 & 3.5 & 51 & $\begin{array}{l}\text { Mixed with other LU and Well } \\
\text { distributed }\end{array}$ \\
\hline Green and park & & 89 & 10.3 & 61 & Well distributed \\
\hline Recreational & & 42 & 4.2 & 20 & $\begin{array}{l}\text { Mixed with other LU \& Well } \\
\text { distributed }\end{array}$ \\
\hline $\begin{array}{l}\text { Offices and light } \\
\text { industry }\end{array}$ & & 57 & 5.4 & 21 & $\begin{array}{l}\text { Mixed with other LU \& Well } \\
\text { distributed }\end{array}$ \\
\hline Health care & & 10 & 1.5 & 12 & Well distributed \\
\hline Religious & & 1 & 0.6 & 8 & \\
\hline Restricted & $\begin{array}{l}\text { Suitable for Park and recreational } \\
\text { not for construction }\end{array}$ & 110 & 7.5 & 0 & $\begin{array}{l}\text { A good case for being a neighbourhood } \\
\text { of LU }\end{array}$ \\
\hline Parking & & 0 & 1.8 & 27 & Well distributed \\
\hline $\begin{array}{l}\text { Hotel and tourist } \\
\text { attraction }\end{array}$ & $\begin{array}{l}\text { Near the beach / recreation / } \\
\text { park is recommended }\end{array}$ & 74 & 6.8 & 26 & Well distributed \\
\hline Shopping centres & & 0 & 1.4 & 20 & $\begin{array}{l}\text { Mixed with other LU \& be accessed } \\
\text { within max } 700 \text { meter }\end{array}$ \\
\hline Save (Supply) & & 0 & 2 & 30 & Well distributed \\
\hline Sum & & 401 & 100 & 1064 & Number of total cells ${ }^{*}$ \\
\hline
\end{tabular}

* Number of total cells to be searched is 1064 . Each cell covers an area of $100 \times 100 \mathrm{~m}$ on the ground. 


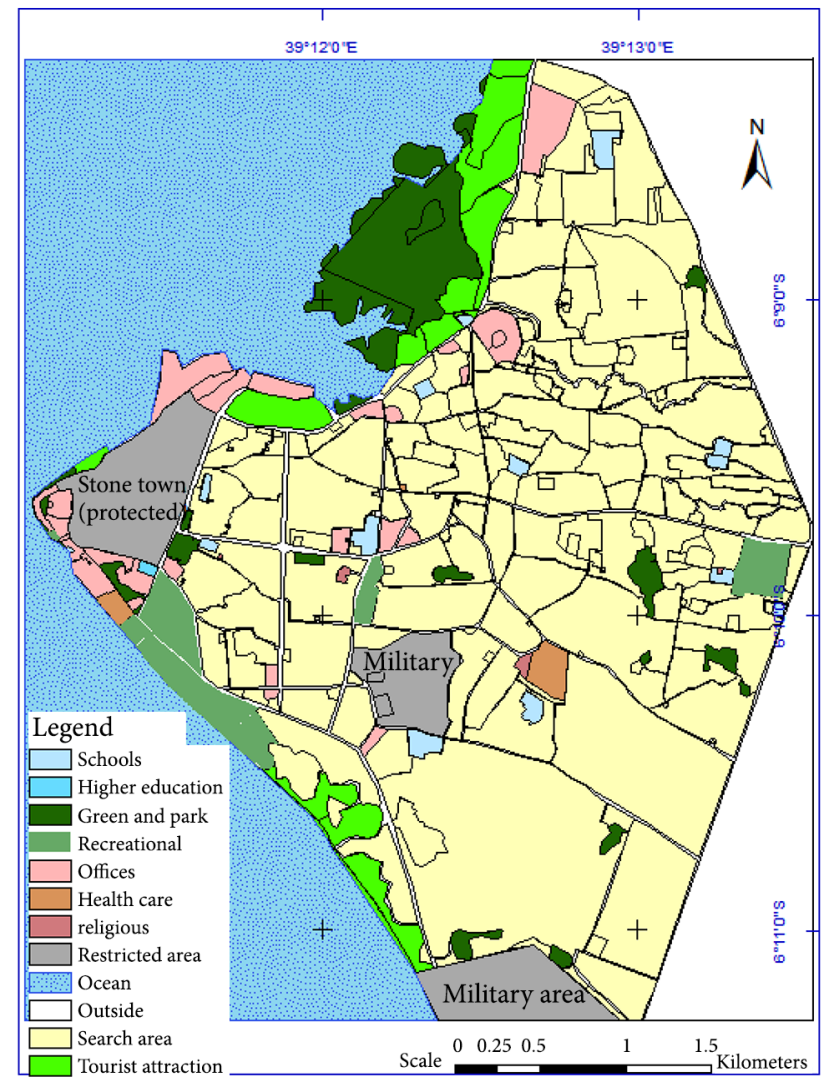

Figure 3. Map showing the existing land-uses of Zanzibar, with a classification where important features are emphasized

centres, sport fields, and residential blocks. Other important land-use such as roads are not incorporated because of the selected size of the cell. However, it was assumed that roads are considered during detailed planning of the city after the general planning is decided.

\subsection{Creating constraint map}

A constraint map shows those cells in which land-uses are not allowed to change during the optimization process. The constrained areas may be protected areas, archaeologic sites, heritage sites, or wetlands. In this study, the stone town area of Zanzibar was kept intact since it is a world heritage site and has vast monumental, historical, and archaeological values. Green and forest areas mostly along the coast were also constrained in the planning process, since they are rich in biodiversity with delicate mangrove swamps. Some major parks and green areas within the city, popular schools (such as Forodhani and Lumumba), offices (government, private, and business buildings), health care centres (hospitals), religious buildings (mosques, temples, and churches), as well as the military areas were also considered constrained areas. Figure 4 shows the constraint map, which is produced for the study area in a raster format. Search area indicated in the Figure is the area or cells that can be searched and assigned the land-use based on the algorithm.

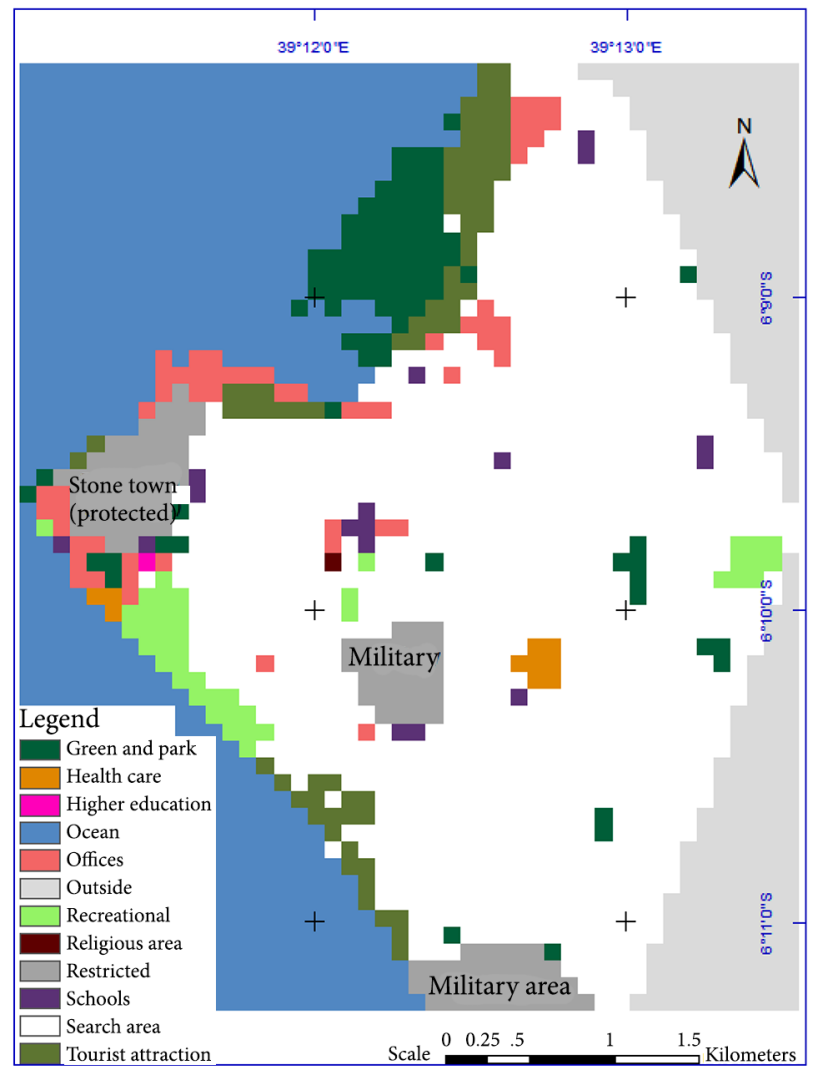

Figure 4. Raster map of Zanzibar used as input to the algorithm, with cells that were restricted (constrained) and the search area, for land-use planning

\subsection{Defining objective functions}

Based on Zanzibar's master plan and the requirements mentioned above, two objective functions, namely maximising the compatibility of land-use types and minimizing travel distance, were designed. These two objectives have also been widely addressed by other researchers, such as (Cao et al., 2011; Masoomi et al., 2012; Haque \& Asami, 2014), since they contain the main aspects of sustainable urban planning. Through optimizing compatibility of land-uses better social interactions are achieved and a more pleasant and healthier environment is created for living. By minimizing travel distances, the accessibility is improved, reflecting the operational efficiency of a city, improving social equity that leads to decreased gas and other emissions generated in the city. As a result, $\mathrm{CO}_{2}$ emissions will be reduced.

The selection of the objective functions was done as prioritized by the respondents. Initially many objectives were proposed but the emphasis was on the objective functions that had priority for urban planners in Zanzibar. However, some of the objective functions (e.g. maximizing suitability) were dropped because of data limitation. From the experience of this study, the usefulness of the technique and the need for available and reliable data for a reliable planning was realized and stakeholders were motivated to include further objective functions in future. In 
the study, the tourist attraction criteria were considered by assigning a higher percentage of the area to the "hotel and tourist attraction" land-use type, and also considering a special case for tourist accessibility, within the objective function relevant to minimum travel distance.

\subsubsection{Optimal compatibility and mix of land-use types}

For comprehensive and sustainable urban planning, it is important to consider a preference of each given land-use type with respect to its compatibility with neighbourhood land-use types. Two land-uses are compatible when two or more land-use types co-exist without any significant negative impact. According to Balsem (2011), planning in Zanzibar should consider separating incompatible landuse types such as industrial land from residential.

In our study area, since all the defined land-uses are compatible with each other, the most compatible land-use is a plan with a high mix of land-uses. In this respect special emphasize was made on a better mix of residential areas with schools, and shopping centres with residential and hotels. It is desired that children can walk to the schools, and therefore all the residential cells should have a distance less than 600 meter from a primary school. A similar requirement was considered for shopping centres in the way that a residential/hotel land-use with a distance of more than 700 meters to a shopping centre will get a compatibility value of zero. The walking distance were based on previous studies about recommendable walking distance for schools, shops, and other public facilities (Lichfield et al., 1975; Daniels \& Mulley, 2013).

The compatibility function has been studied by many authors (Ligmann-Zielinska et al., 2008; Neema \& Ohgai, 2010; Cao et al., 2011; Masoomi et al., 2012; Liu et al., 2013; H. Wang et al., 2013; Haque \& Asami, 2014). As mentioned earlier, an optimal land-use in this study is one with the highest mix of land-use types. This means that the highest possible variation in combination of land-use types is desired. To formulate this criterion, it was supposed that any cell (land-use) has a direct relation with its neighbours and hence a kernel of $3 \times 3$ cells was defined to calculate the compatibility. The value of a mix of land-use types of a cell at the centre of kernel is equal to 9 minus the numbers of neighbouring cells with the same land-use types as centre. The final objective function value is the sum of the value of compatibility for the designed cells. Hence, the objective function is defined by

$$
F 1=\operatorname{maximize} \sum_{i=1}^{1467} \sum_{n=1}^{8}(9-n),
$$

where $i$ denotes the number of the search cells and $n$ is the number of neighbour cells with similar land-use types as the center cell. Because 52.6 percent of the searched area is residential areas hence compatibility of other land-uses are determined based on the total value of compatibility function. Improving compatibility value shows how many cells are, in total, mixed better with their neighbourhoods.

\subsubsection{Minimizing travel distance}

When determining the accessibility (the minimum travel distance) for a location the assumption is that people travel only to the necessary neighbouring land-use in the area. In the algorithm, residential cells that have shortest distance to a particular land-use types or activity are grouped together. The centres of cells are assumed as travel starting/destination points to simplify the implementation of the algorithm.

The input raster map (Figure 3) is a grid network of cells each representing a land-use type. A link between cells is a line connecting their centre points. The centre points (as nodes) represent the characteristics of land-use types and are also used to create links between land-use types. Minimum travel distance is based on travel from residential or tourist land-use types to the other land-use types. Based on previous studies and also the interview with the experts, tourists in Zanzibar travel to the tourist attractions of the city which are mainly located in the stone city (Salim \& Mwaipopo, 2016).

Since tourists mainly travel for visits, shopping, and recreational purposes, the travel distances from hotels to the stone city, green and park areas, the recreational area in the north of the study area, the western coast side of the study area, the airport, and the harbour were considered to be optimized. In this way, the land-use planning optimization is conducted with special attention on preparing the city for tourism.

The objective function for minimizing the travel distances is defined as below:

$$
\begin{aligned}
& F 2=\operatorname{Minimize}\left(\sum_{i=1}^{n} \sum_{j=1}^{m} M_{-} \text {dist }_{i j}+\right. \\
& \left.\sum_{k=1}^{p} \sum_{l=1}^{q} M_{-} \text {dist }_{k l}\right),
\end{aligned}
$$

where $i$ represents residential cells and $n$ is the total number of residential cells; $j$ represents destination cells of residential cells (schools, shopping, etc.), and $m$ is the number of destinations (here $m=10$ ); $k$ represents tourist cells and $p$ is the total number of tourist cells; $l$ represents destination cells for tourists (stone city, recreational area, etc.) and $q$ is the number of destinations (here $\mathrm{m}=5$ ), and $M_{-}$dist $_{i j}$ shows the distance from a residential cell to the nearest cell of a target destination. First, by applying a function, distances from a residential cell to the destination cells are achieved and the minimum distance for each destination is calculated. The process for the tourist cells is the same, and the only difference is the destination cells.

Based on plot coverage standards, $25 \%$ of each residential cell $(100 \times 100 \mathrm{~m})$ was assumed to be used as build up area and the rest being used for road network, parking, and/or green areas (Lupala, 2002; Silva, 2015). An average of 140 households were assumed to live in a 4 floor building ( 35 in each floor), with an average of $70 \mathrm{~m}^{2}$ area for each flat. 


\subsection{Implementation of the multi-objective optimization genetic algorithm}

The NGSA II algorithm was written in MATLAB (MathWorks, 2015). There were several stages of the implementation of the algorithm. A flow chart (Figure 5) shows the process of the algorithm. In stage A required parameters of the algorithms including number of primary population, number of runs, number of offspring (cross over populations), number of offspring (mutation populations), and land-uses proportions are defined. Then, several alternative land-use plans, called primary population or individuals, were randomly created. In this stage randomly generated plans are checked to test the conditions of landuses such as schools and shopping centres which are well distributed. If the requirements are not passed by applying a function, positions of schools and shopping centres will be replaced with residential cells. The process continues until the requirements are achieved. After that two objective values are calculated. This process continues to create $\mathrm{np}$ number of individuals as primary population Pp. In this stage the number of primary individuals is important, since in a case that few individuals are used there is a risk of lack of diversity of population which is needed for change and progress in the evolutionary process of the algorithm, which may result in an early convergence. On the other hand, with a higher number of individuals complexity arises which leads to slow convergence (Abraham et al., 2005). After that, the created populations are sorted

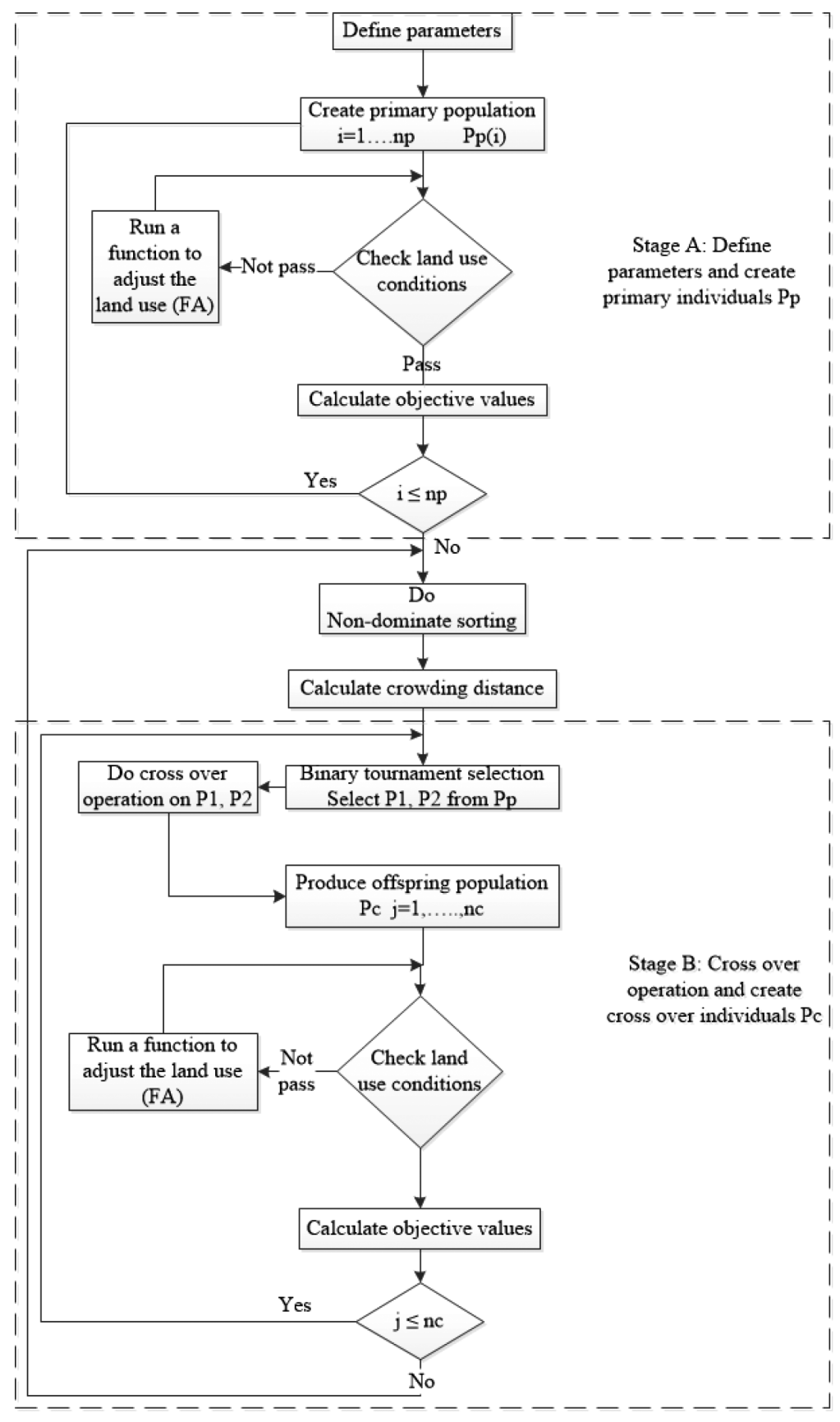

Figure 5. Flow chart showing the NGSA II algorithm implemented in this study 
by a non-dominating sorting method and crowding distances are calculated.

Stage B: Through applying binary tournament selection, two individuals are selected for the cross over process. After applying cross over, the proportions of the land-uses are changed. Therefore, a function is applied to correct the proportions of land-uses. At this stage, the proportions of all land-uses are checked. All land-uses which have either a higher or a lower proportion compared to the defined proportions are selected, and by randomly removing or adding them the required amounts the defined proportions are achieved. After that a new generated individual (cell) is checked for land-use conditions. If the requirements are not met a function is applied, and positions of schools and shopping centers are replaced by residential cells. The process continues until the requirements are fulfilled. After that two objective values are calculated. This process continues to create nc number of individuals as cross over population $(\mathrm{Pc})$.

The full process in stage $B$ is then repeated with only one condition, and that is applying a mutation process instead of a cross over process, and finally nm numbers of individuals are created as mutation populations (Pm). After creating the primary, cross over and mutation populations are merged together and sorted through non-dominating sorting. Crowding distances are calculated and based on Figure 5 an np number of individuals which is equal to the primary population number are selected. Then the run is completed and the process from stage B continues until the termination criterion is achieved.

\subsection{Analysis of results}

The performance of the land-use optimization algorithm based on NGSA-II was evaluated for validity and reliability. The NSGA-II algorithm uses heuristic search methods, and due to the random elements in the search process the results change when the algorithm is run again. Therefore, a reliability analysis was carried out in order to evaluate the algorithm. In the analysis performed, the algorithm was run six times with the same parameters; population size of 50 and number of generations equal to 1000 . Evaluation results for the six repetitions are given in Table 2 and Figure 6. Table 2 shows that accessibility distance ranged from 8765.498 to $8817.804 \mathrm{~km}$, while the compatibility values ranged from 5130.784 to 5180.300 for the six runs of the algorithm.

Table 2. Outcome of repeatability analysis of the algorithm

\begin{tabular}{|c|c|c|}
\hline No & $\begin{array}{c}\text { Accessibility distance (km per } \\
\text { one travel from all residents and } \\
\text { tourists) }\end{array}$ & Compatibility \\
\hline 1 & 8765.498 & 5159.639 \\
\hline 2 & 8769.344 & 5161.637 \\
\hline 3 & 8803.760 & 5130.784 \\
\hline 4 & 8769.340 & 5161.610 \\
\hline 5 & 8817.804 & 5164.649 \\
\hline 6 & 8773.652 & 5180.300 \\
\hline
\end{tabular}

The results of the six runs (R1 to R6) from Table 2 are plotted in Figure 6 below. The differences among the graphs are very minor. In other words, the results show that there is no significant change in both objectives' values after 1000 generations, and therefore the performance of the algorithm is stable and reliable.

Investigation on sensitivity was carried out by varying the constant parameters in the NSGA-II algorithm, including the number of generations and the number of individuals in each generation, and then observing the possible changes in the results. The functional evaluation, which is the product of the multiplication of these two parameters, was fixed to 50.000 . The algorithm was run for six times with different settings of the two parameters

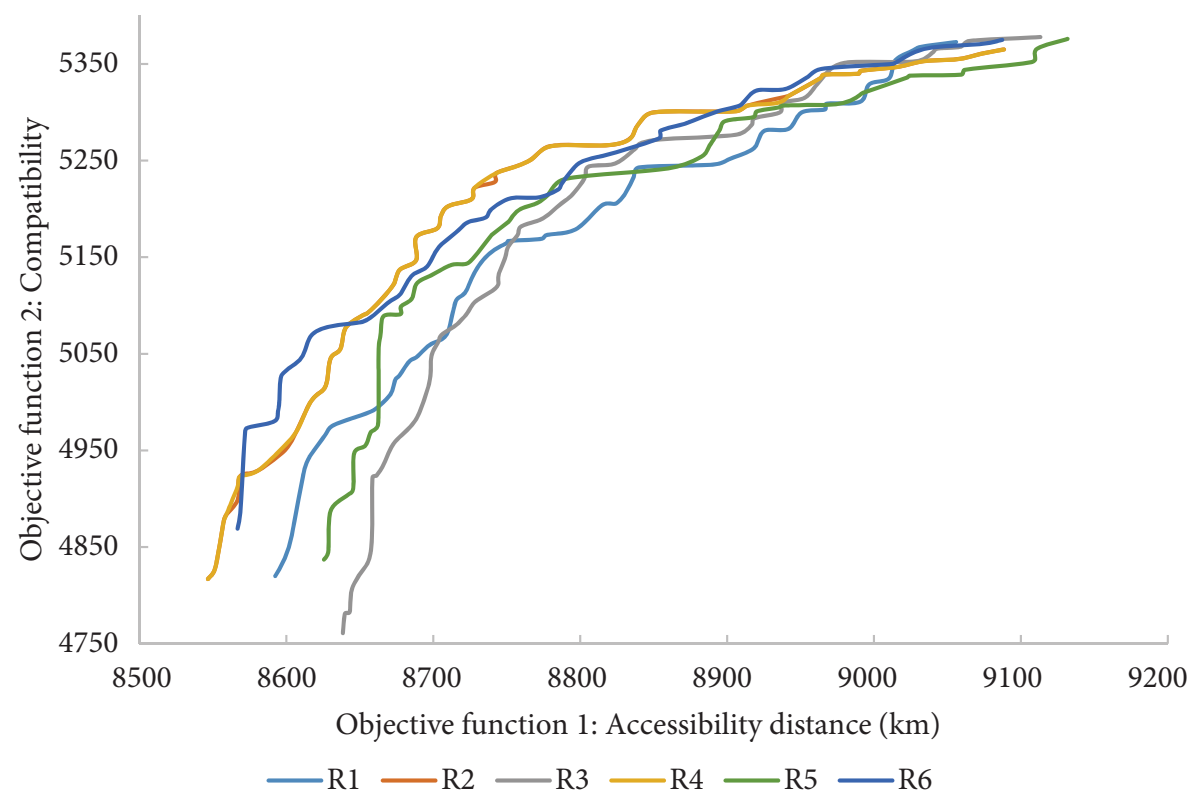

Figure 6. Pareto fronts for repeatability investigation (1000 iterations) 
as shown in Table 3. The results in Table 3 show that the number of solutions in first Pareto front ranged from 20 to 69 , accessibility distance ranged from 8483.720 to $9205.227 \mathrm{~km}$, and the compatibility values ranged from 4884.554 to 5484.020 .

Table 3. Outcome of parameter settings of the algorithm

\begin{tabular}{|c|c|c|c|c|c|}
\hline No & $\begin{array}{c}\text { Popu- } \\
\text { lation } \\
\text { Size }\end{array}$ & $\begin{array}{c}\text { Number } \\
\text { of gene- } \\
\text { rations }\end{array}$ & $\begin{array}{c}\text { Number } \\
\text { of } \\
\text { solutions } \\
\text { in } 1^{\text {st }} \\
\text { Pareto } \\
\text { front }\end{array}$ & $\begin{array}{c}\text { Accessibility } \\
\text { distance } \\
\text { (km per one } \\
\text { travel from all } \\
\text { residents and } \\
\text { tourists) }\end{array}$ & com- \\
patibility \\
\hline 1 & 20 & 2500 & 20 & 8483.720 & 5484.020 \\
\hline 2 & 25 & 2000 & 25 & 8547.280 & 5472.256 \\
\hline 3 & 50 & 1000 & 50 & 8903.202 & 5120.695 \\
\hline 4 & 75 & 715 & 65 & 9023.297 & 5048.848 \\
\hline 5 & 80 & 620 & 69 & 9143.863 & 5018.997 \\
\hline 5 & 100 & 500 & 32 & 9119.683 & 4886.917 \\
\hline 6 & 125 & 400 & 29 & 9205.227 & 4884.554 \\
\hline
\end{tabular}

The Pareto fronts for the six runs are plotted in Figure 7. As Figure 7 shows, a more optimum Pareto front was achieved by decreasing the population and increasing the number of generations, as expected. Based on the results presented, a generally good robustness of the results of the optimization algorithm was revealed.

\section{Results}

As a result of the sensitivity analysis, it was revealed that a primary population of 20 individuals with 2500 runs has the most optimized results for the objective functions.
Therefore, these parameters were selected to determine final results and plans. Figure 8 shows 20 random primary individuals after sorting them into 7 fronts based on the rank and crowding distance criteria. As shown in Figure 8 , the variation between the values of the objective functions is considerable. The travel distance values range from $9.600 \mathrm{~km}$ to $10.375 \mathrm{~km}$, and compatibility values range from 4505 to 4710 .

Individuals in a population were ranked by a Pareto front and had a crowding distance to guarantee the diversity of individuals. All weak individuals that were left out in the process of cross over and mutation were removed from the population, and hence the speed of the algorithm execution increased (Abraham et al., 2005). Figure 9 shows the Pareto front for a population of 20 for 1000 and 2500 runs, which shows how iteration enhances both the objective functions. For 1000 iterations the distance range for compatibility function values has increased from 5364 to 5480 , and the range of travel distances has decreased from $8623 \mathrm{~km}$ to $8488 \mathrm{~km}$. These changes illustrate the evolution of the algorithm after 1500 additional runs.

For the 2500 iterations, the distance ranged from 8488 to $9107 \mathrm{~km}$, and values for compatibility varied from 4709 to 5480. Compared to the results from the first Pareto front and the 1000 runs, the minimum travel distances have been reduced by $1112 \mathrm{~km}$. The compatibility optimal values have been increased by 116 cells compared to primary population and 1000 runs, respectively.

Each point on the Pareto front is a potential optimum solution for land-use planning, while there is always a trade-off between the possible solutions. A decision-maker may select a solutions based on his/her preference to stress a specific objective function. Figures 10, 11, and 12 show three different land-use maps produced by selecting

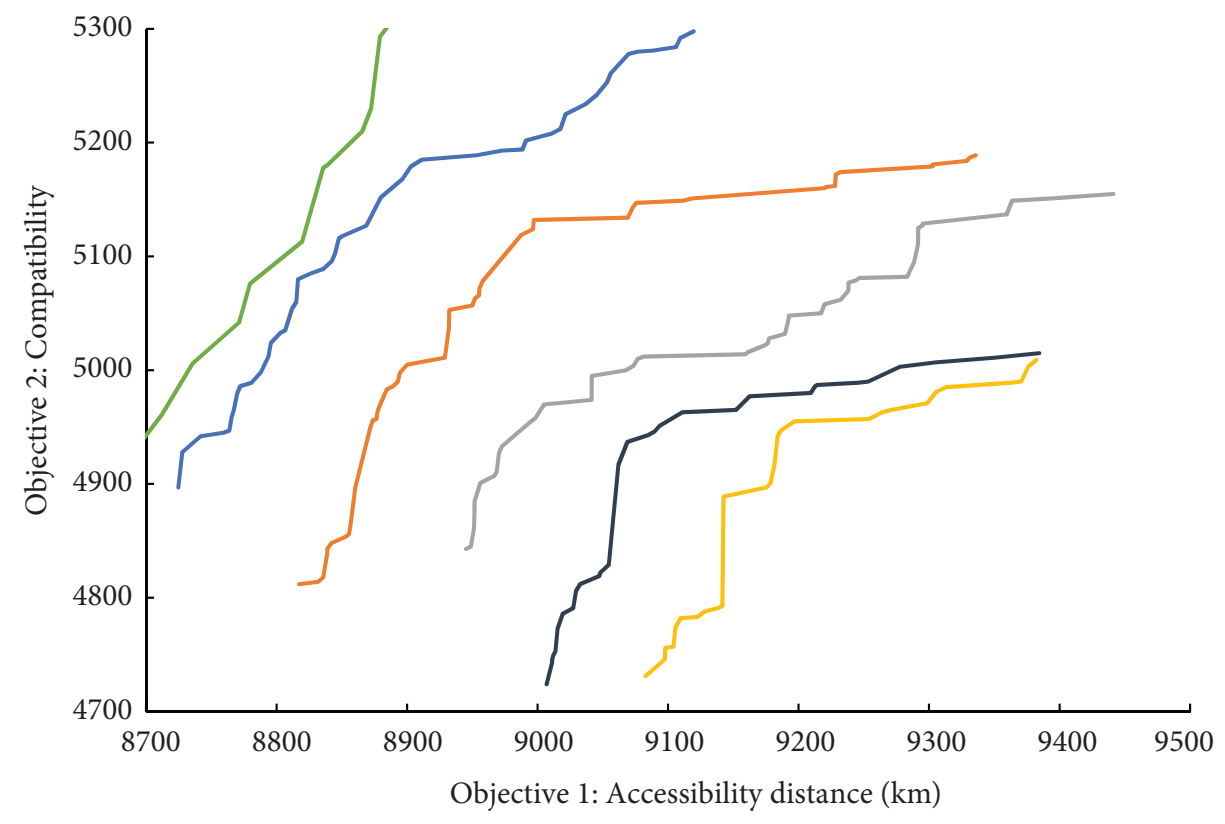

$\longrightarrow \mathrm{S} 1-\mathrm{S} 2-\mathrm{S} 3-\mathrm{S} 4-\mathrm{S} 5-\mathrm{S} 6$

Figure 7. Pareto fronts for the six runs in the sensitivity investigation 
three different solutions $(1,2,3)$ from the Pareto front shown in Figure 9.

The optimum solution resulting from stressing the "maximizing compatibility" objective function is given in Figure 10. In this case, the travel distance is 9106.86 $\mathrm{km}$ with a total compatibility value of 5480 cells. The solution from stressing the "minimizing the travel distance" objective function is shown in Figure 11, with a travel distance of $8487.92 \mathrm{~km}$ and a compatibility value of 4709. If a solution is sought which gives the same weights to both the objective functions, the travel distance of $8758.68 \mathrm{~km}$ and a compatibility value of 5108 is an optimum solution. The map for the trade-off function is given in Figure 12.

These three maps illustrate optimised land-use plans based on the objective functions. It should be noted that each of the optimal solutions can be interpreted as a prototype solution (plan) which cover the concerns of specific stakeholders, with respect to a particular objective. It means that one solution might only consider the concerns and requirements of a particular group of stakeholders. For instance, in this work the travel distance may focus more on environmental aspects, while social concerns are stressed in the objective of compatibility.

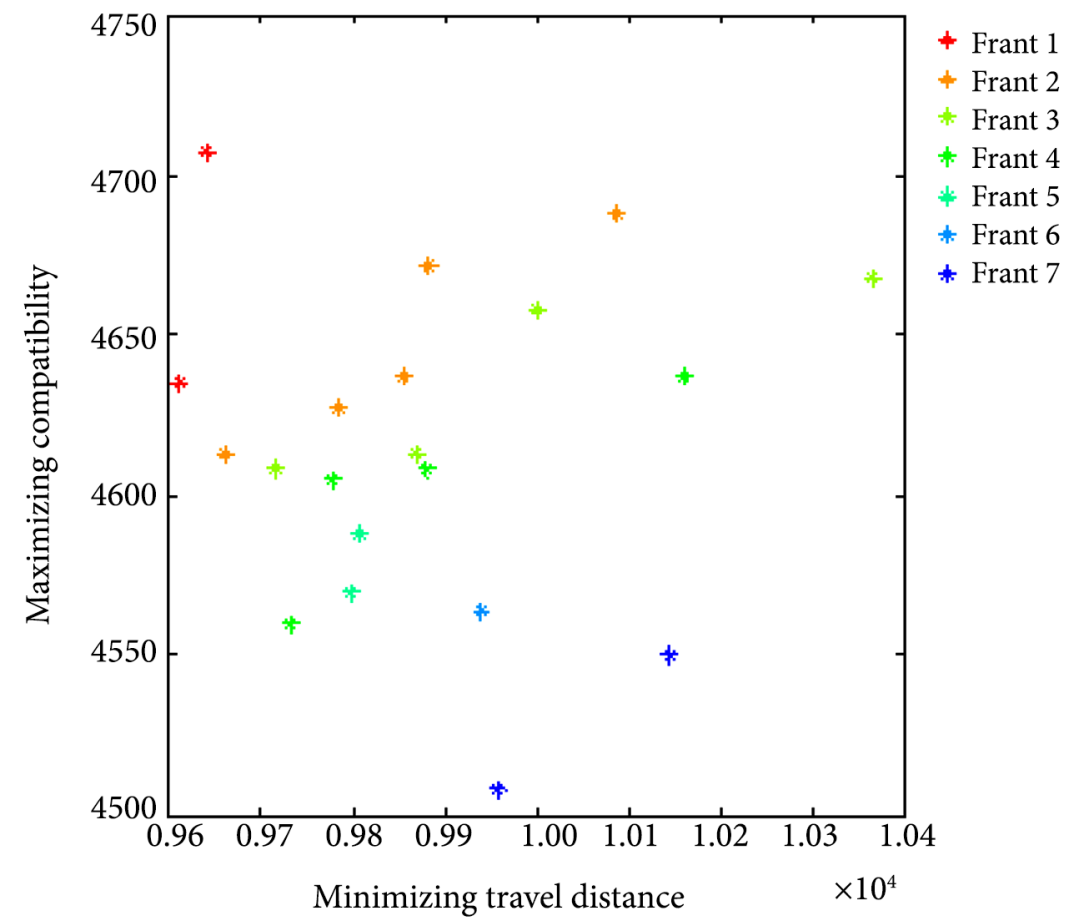

Figure 8. The first Pareto front results from the objective values of 20 primary individuals after sorting them based on their ranks and crowding distances

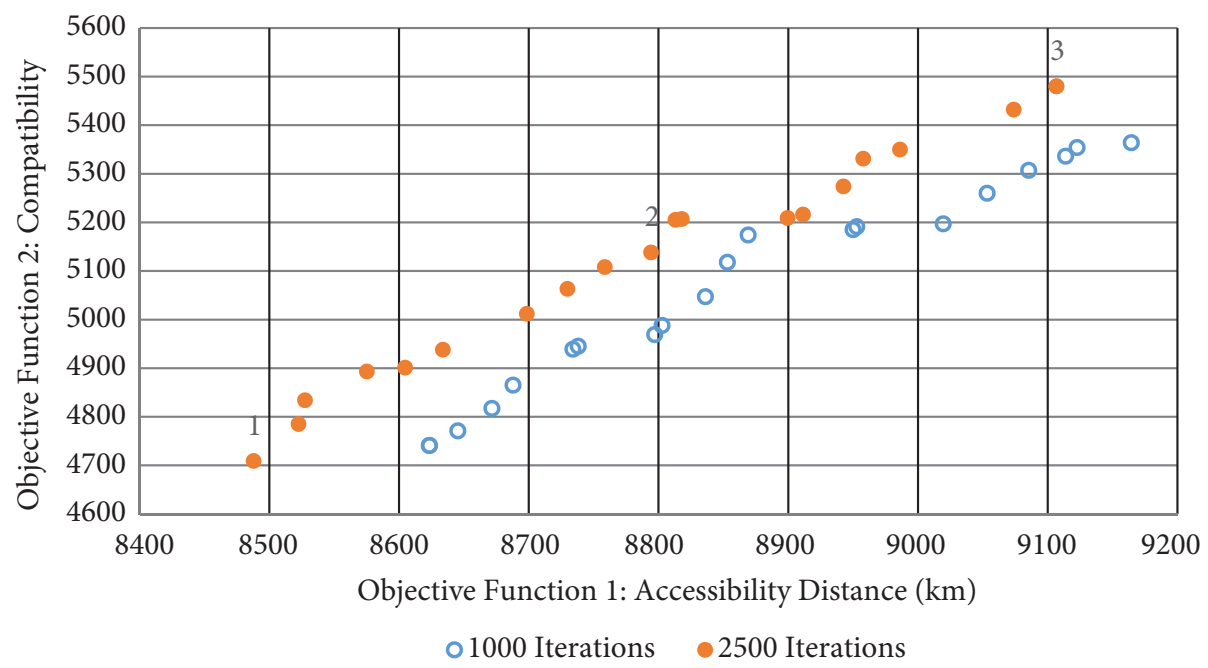

Figure 9. Optimal Pareto front after 1000 and 2500 iterations respectively, based on two objectives of minimum travel distance $(\mathrm{km})$ and compatibility. " 1 " and " 3 " are two possible solutions by emphasizing on accessibility and compatibility respectively. "2" is a solution by giving the same weights to the two objective functions 

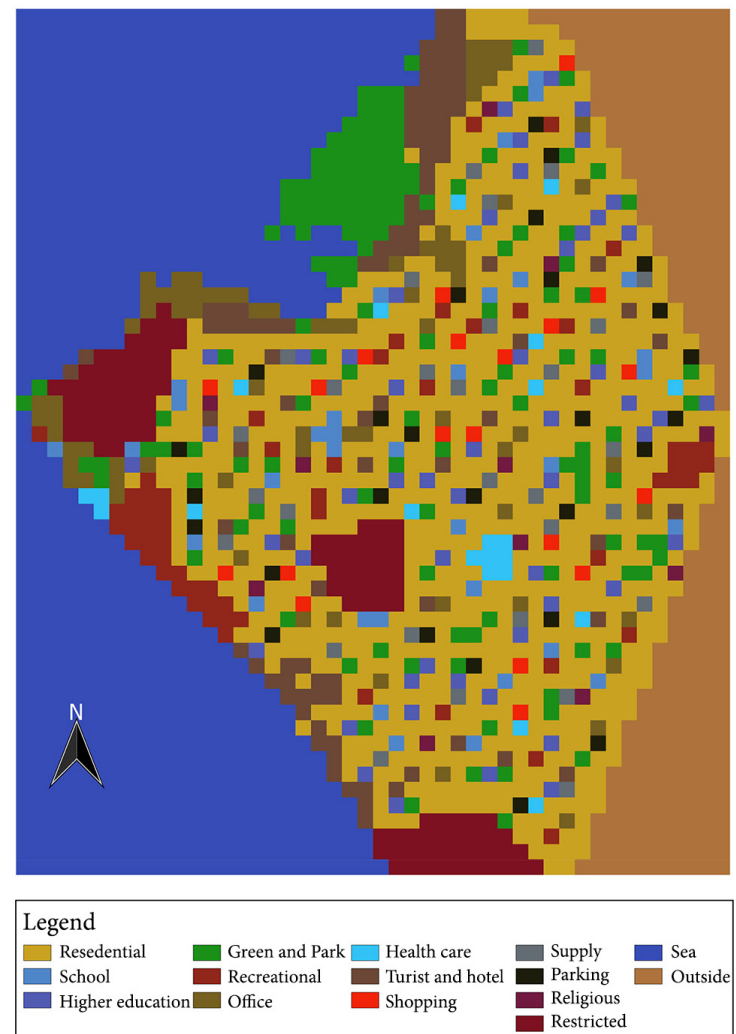

Figure 10. A land-use map from Zanzibar city (case study area), when the objective function of maximizing compatibility is prioritized (selecting point 3 from Figure 9)
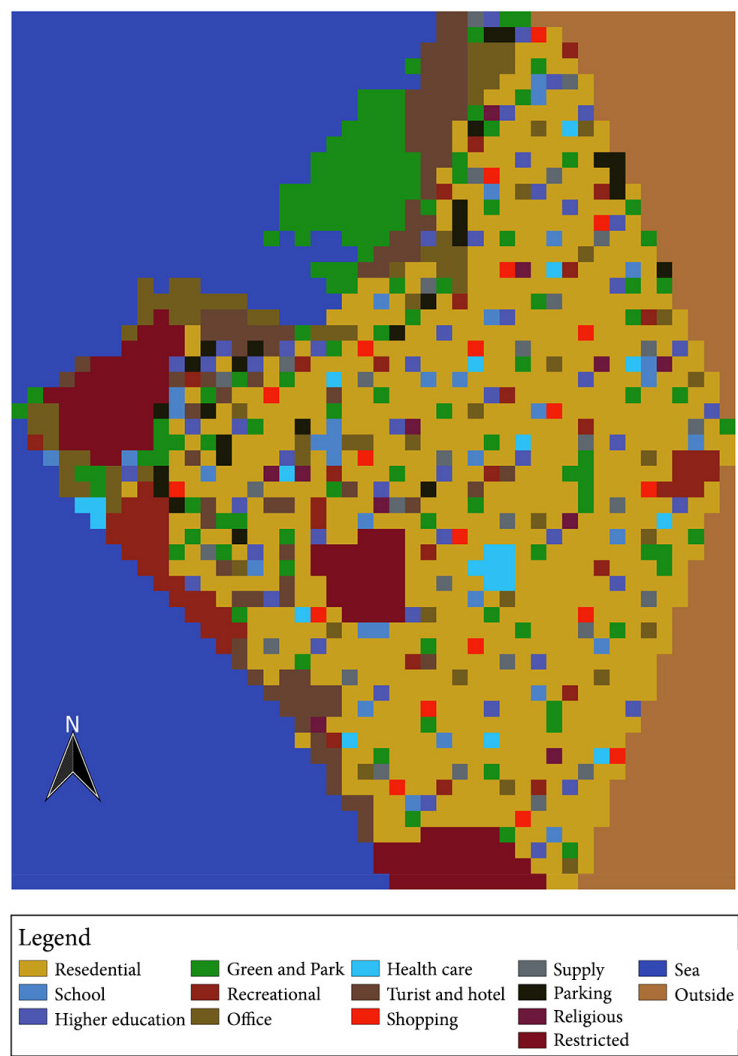

Figure 11. A land-use map from Zanzibar city (case study area), when the objective function of minimizing travel distance is prioritized (selecting point 1 from Figure 9)
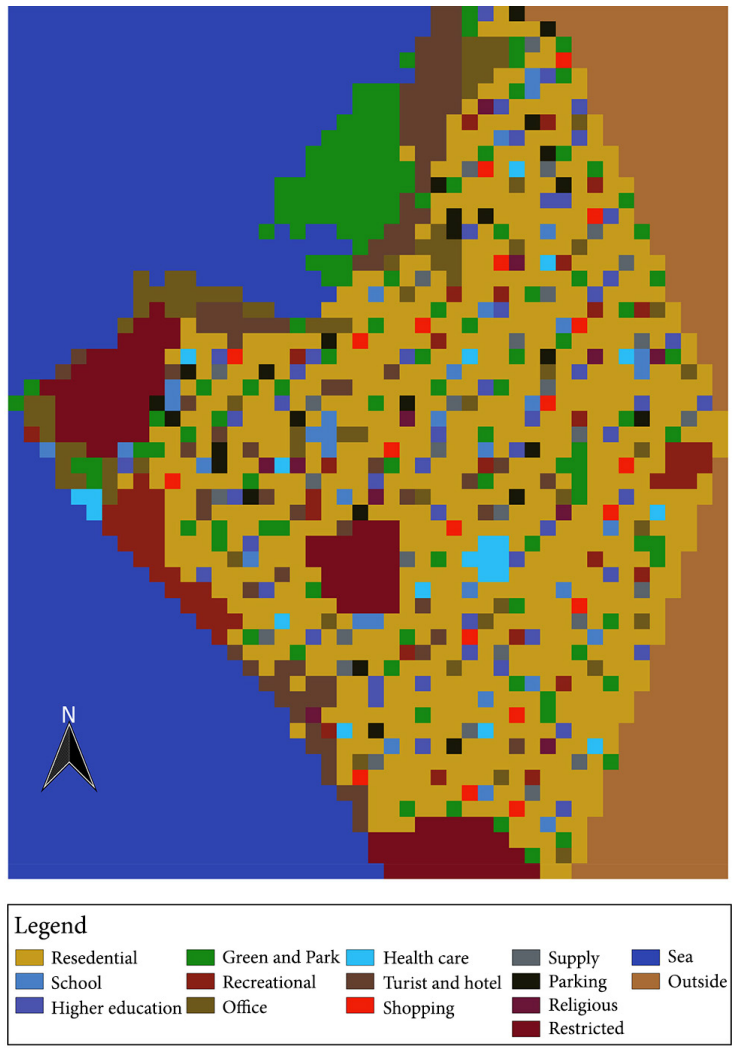

Figure 12. A land-use map from Zanzibar city (case study area), when a trade-off between compatibility and travel

distance is applied (selecting point 2 from Figure 9)

The results presented above cannot be regarded as a final solution for the land-use planning of Zanzibar city. However, they can be used as a primary base plan and input to decision-makers to facilitate the procedure for detailed planning on how and where to assign different land-uses.

\section{Discussion and conclusions}

Land-use planning is a complicated task, since it needs finding a balance among different social, economic and environment factors which are generally conflicting each other. Traditional techniques are not efficient enough for making the planning properly. This is a major problem, not least in African countries.

In this study, a multi-objective optimization technique was used for land-use urban planning in Zanzibar. The planning was conducted with the aim of optimizing land-use compatibility (high mix of land-uses) and travel distance with focus on tourism. Unlike the traditional multi-criteria decision-making techniques, the effect of the experts' preferences on the decision-making process was shifted from the early stages of planning (weighting the criteria) to the later stages (selecting a solution from a list of optimum trade-off solutions). In other words, the technique depends mainly on the objective functions and hence has the advantage of reducing the risk of making biased decisions, influenced by interests of experts or stakeholder groups. 
The technique is based on concurrent optimization of the objective functions, with no specific limitation. It provides the possibility of involving a broader range of stakeholders, by including their requirements (and the relevant objective functions) in the planning/optimization process. Worth to be noted is that defining objective functions which may overlap should be avoided to reduce the risk of bias. In addition, the convergence of the algorithm is important, while defining the functions.

Each of the optimal solutions can be interpreted as a prototype solution (plan) which can be used by decisionmakers as a base to prepare a detailed plan. Such a prototype provides planners with an insight about the socioeconomic and environmental influences of different decisions on the city.

In this study, the results were presented to a selected group of interviewees, including key experts in urban planning. In a meeting the model and the outcomes including the alternative solutions for land-use planning were presented and discussed. The interviewees were impressed of the results and how the proposed methodology can provide them with prototype solutions (plans), which include trade-off between conflicting objective functions. They argued that such plans can be used as a base for a better decision-making for detailed planning. The results can provide decision-makers with an insight on the costs and the negative influences of improper decisions on landuse planning. For example, from the experience of this study, and by considering the pollution which is produced in the area as a whole, a decision-maker can realize that focusing only on increasing the compatibility may increase the travel distances by at least $600 \mathrm{~km}$ per day or $219.000 \mathrm{~km}$ per year, of which for a district makes sense. This amount is remarkable with huge negative influences on air quality and also on reduction of waste of energy.

One of the main characteristics of this work is that the algorithm has been developed in order to consider the requirements and conditions of the objectives. In the studies conducted by other researchers, Neema and Ohgai (2010), Cao et al. (2011), Liu et al. (2013) the number of land-uses is changeable, while in this study a predefined number of land-uses is kept constant. This makes the developed algorithm to represent the reality of urban problems regarding urban land-use planning in a more realistic way.

This study shows that evolutionary multi-objective optimization algorithms can be properly used for land-use optimization, based on the relevant objective functions. For including more influencing factors in the optimization process, one may define and add more objective functions to the algorithm, based on the requirements of the case study area. In addition, an objective function, e.g. travel distance, may be formulated in different ways by considering the travel behaviour of citizens, the commuting from outside of the planning area, policies and regulations, etc. in the formulation of the function. For a comprehensive urban planning, it is required that different groups of stakeholders and experts come together to define objective functions, which are essential to be considered for the planning of an urban area. The use of Multi-objective functions for land-use planning and other type of problems, where different conflicting criteria are influencing, is recommended.

\section{Acknowledgements}

The first author of this study acknowledges the financial support of SIDA, Sweden. The authors thank all of the people who assisted with data collection and provided scientific advice regarding urban land-use planning in Zanzibar, Tanzania.

\section{References}

Abraham, A., Jain, L., \& Goldberg, R. (2005). Evolutionary multiobjective optimization: Theoretical advances and applications. London: Springer-Verlag. https://doi.org/10.1007/1-84628-137-7

Aguirre, A. H., Rionda, S. B., Coello Coello, C. A., Lizárraga, G. L., \& Montes, E. M. (2004). Handling constraints using multiobjective optimization concepts. International Journal for Numerical Methods in Engineering, 59(15), 1989-2017. https://doi.org/10.1002/nme.947

Ahmadi, F., \& Toghyani, S. (2011). The role of urban planning in achieving sustainable urban development. OIDA International Journal of Sustainable Development, 2(11), 23-26.

Ananda, J., \& Herath, G. (2009). A critical review of multi-criteria decision making methods with special reference to forest management and planning. Ecological Economics, 68(10), 2535-2548. https://doi.org/10.1016/j.ecolecon.2009.05.010

Anderson, W. (2013). Leakages in the tourism systems: case of Zanzibar. Tourism Review, 68(1), 62-76.

https://doi.org/10.1108/16605371311310084

Auma, S. L. A. (2012). Integrating community participation for urban redevelopment planning in Zanzibar town. Enschede, The Netherlands.

Awadh, G. O. (2007). Tourism and Heritage Conservation: 21st Century Challenge. Case: Zanzibar Stone Town. Paper presented at the Manifestation of African Perspectives Dialogues on Urbanism and Architecture, Faculty of Architecture - TU Delft, The Netherlands.

Azzan, R. M., \& Ufuzo, S. S. (2005). The role of spatial data and infrastructure in an information society: Conflicts and implications for Zanzibar. Paper presented at the FIG Working Week 2005 and GSDI-8 From Pharaohs to Geoinformatics, Cairo, Egypt.

Babakan, A. S., \& Alimohammadi, A. (2015). An agent-based simulation of residential location choice of tenants in Tehran, Iran. Transaction in GIS. https://doi.org/10.1111/tgis.12144

Balling, R. J., Brown, M. R., \& Day, K. (1999). Multiobjective urban planning using genetic algorithm. Journal of Urban Planning and Development, 125(2), 86-99. https://doi.org/10.1061/ (ASCE)0733-9488(1999)125:2(86)

Balsem, T. (2011). Report of the International Land Use Planning Advisor's Mission.

Bissell, W. C. (2011). Urban sustainability at the limits: Development rhetorics and realities in Tanzania. Development, 54(3), 317-324. https://doi.org/10.1057/dev.2011.63

Cao, K., Batty, M., Huang, B., Liu, Y., Yu, L., \& Chen, J. (2011). Spatial multi-objective land use optimization: extensions to the Non-Dominated Sorting Genetic Algorithm-II. International Journal of Geographical Information Science, 25(12), 1949-1969. https://doi.org/10.1080/13658816.2011.570269 
Coello, C. A. C., Van Veldhuizen, D. A., \& Lamont, G. B. (2002). Evolutionary algorithms for solving multi-objective problems $(2$ Ed.). New York: Springer. https://doi.org/10.1007/978-1-4757-5184-0

Colomi, A., Dorigo, M., \& Maniezzo, V. (1991). Distributed optimization by Ant colonies. Paper presented at the Proceedings of ECAL91 - European Conference on Artificial Life, Paris, France.

Creswell, J. W., \& Plano Clark, V. L. (2007). Designing and conducting mixed methods research (Vol. 2009). Thousand Oaks, CA: SAGE Publications.

Daniels, R., \& Mulley, C. (2013). Explaining walking distance to public transport: the dominance of public transport supply. Journal of Transport and Land Use, 6(2), 5-20. https://doi.org/10.5198/jtlu.v6i2.308

Datta, D., Deb, K., \& Fonseca, C. M. (2007). Multi-objective evolutionary algorithms for resource allocation problems. Paper presented at the 4th International Conference, EMO 2007, Matsushima, Japan, March 2007.

https://doi.org/10.1007/978-3-540-70928-2_32

Deb, K. (2001). Multi-Objective Optimization using evolutionary algorithms. Chichester: Wiley.

Deb, K. (2014). Multi-objective Optimization. In E. K. Burke \& G. Kendall (Eds.), Search Methodologies: Introductory Tutorials in Optimization and Decision Support Techniques (2 ed.). London: Springer.

https://doi.org/10.1007/978-1-4614-6940-7_15

Deb, K., Pratap, A., Agarwal, S., \& Meyarivan, T. (2002). A Fast and elitist multi-objective genetic algorithm: NSGA-II. IEEE Transactions on Evolutionary Computation, 6(2), 182-197. https://doi.org/10.1109/4235.996017

Dodman, D., McGranahan, G., \& Dalal-Clayton, B. (2013). Integrating the Environment in urban planning and management key principles and approaches for cities in the 21st century. Nairobi: United Nations Environment Programme.

Dorigo, M. (1992). Optimization, learning and natural algorithms (PhD Thesis). Polytechnic University of Milan, Milan, Italy.

Fonseca, C. M., \& Fleming, P. J. (1993, 28 May). Multiobjective genetic algorithms. Paper presented at the IEE colloquium on "Genetic Algorithms for Control Systems Engineering", London.

Forson, E. K. (2011). Estimating socio-economic value of cycling using opportunity cost methodology (Master of Science). Twente, Enschede.

Fudenberg, D., \& Tirole, J. (1983). Game theory. MIT Press.

Haji, H. A., Azzan, R. M., \& Ufuzo, S. S. (2006). Evolution of spatial planning in Zanzibar and its Influence. Paper presented at the XXIII FIG Congress, Munich, German.

Hall, A. (2009). A Green lung for the stone town: The challenge of developing a green structure for the users of Zanzibar historical city core (A Master Thesis in Landscape Architecture). Swedish University of Agricultural Sciences, Alnarp.

Haque, A., \& Asami, Y. (2011). Optimizing urban land-use allocation: case study of Dhanmondi Residential Area, Dhaka, Bangladesh. Environment and Planning B: Planning and Design, 38(3), 388-410. https://doi.org/10.1068/b35041

Haque, A., \& Asami, Y. (2014). Optimizing urban land use allocation for planners and real estate developers. Computers, Environment and Urban Systems, 46, 57-69.

https://doi.org/10.1016/j.compenvurbsys.2014.04.004

Hikmany, A. H. (2012). Land planning authorities and sustainable tourism in Zanzibar. Paper presented at the FIG Working Week 2012: Knowing to Manage the Territory, Protect the Environment, Evaluate the Cultural Heritage, Rome, Italy. https:// doi.org/10.2139/ssrn.2687645
Horn, J., Nafpliotis, N., \& Goldberg, D. E. (1994, 27-29 June). A niched Pareto genetic algorithm for multiobjective optimization. Paper presented at the Proceedings of the first IEEE conference on evolutionary computation. IEEE world congress on computational intelligence, Orlando, FL, USA. https://doi.org/10.1109/ICEC.1994.350037

Hwang, C. L., \& Yoon, K. (1981). Multiple attribute decision making: Methods and applications. New York: Springer-Verlag. https://doi.org/10.1007/978-3-642-48318-9

Jebari, K., \& Madiafi, M. (2013). Selection methods for genetic algorithms. International Journal of Emerging Sciences, 3(4), 333-344.

Karaboga, D. (2010). Artificial bee colony algorithm. Scholarpedia, 5(3), 6915. https://doi.org/10.4249/scholarpedia.6915

Kennedy, J. (1997). The particle swarm: social adaptation of knowledge. Paper presented at the Proceedings of IEEE International Conference on Evolutionary Computation. IEEE. https://doi.org/10.1109/ICEC.1997.592326

Kennedy, J., \& Eberhart, R. (1995). Particle Swarm optimization. Paper presented at the Proceedings of IEEE International Conference on Neural Networks, Perth, WA. https://doi.org/10.1109/ICNN.1995.488968

Khatib, A., Mmochi, A. J., Mpatane, M., \& Kombo, M. (2004). Country Report Tanzania. Zanzibar.

Köksalan, M., Wallenius, J., \& Zionts, S. (2011). Multiple criteria decision making: From early history to the 21st century. World Scientific Publishing Company. https://doi.org/10.1142/8042

Lichfield, N., Kettle, P., \& Whitbread, M. (1975). Evaluation in the planning process. Oxford: Pergamon Press. https://doi.org/10.1016/B978-0-08-017843-1.50008-5

Ligmann-Zielinska, A., Church, R. L., \& Jankowski, P. (2008). Spatial optimization as a generative technique for sustainable multiobjective land use allocation. International Journal of Geographical Information Science, 22(6), 601-622. https://doi.org/10.1080/13658810701587495

Liu, X., Ou, J., Li, X., \& Ai, B. (2013). Combining system dynamics and hybrid particle swarm optimization for land use allocation. Ecological Modelling, 257(2013), 11-24. https://doi.org/10.1016/j.ecolmodel.2013.02.027

Lupala, J. M. (2002). Urban types in rapidly urbanising cities: Analysis of formal and informal settlements in Dar es Salaam, Tanzania (PhD), KTH, Stockholm.

Mahmoud, I. I. (2013). Inclusion of small-scale farmers in the spice value chain in Zanzibar, Tanzania. (MA). International Institute of Social Studies (ISS), The Hague.

Makame, M. K., \& Boon, E. K. (2008). Sustainable tourism and benefit-sharing in Zanzibar: The Case of Kiwengwa-Pongwe forest reserve. Journal of Human Ecology, 24(2), 93-109. https://doi.org/10.1080/09709274.2008.11906105

Mansourian, A., Taleai, M., \& Fasihi, A. (2011). A Web-based spatial decision support system to enhance public participation in urban planning process. Journal of Spatial Science, 56(2), 269-287. https://doi.org/10.1080/14498596.2011.623347

Martin-Moreno, R., \& Vega-Rodriguez, M. A. (2018). Multiobjective artificial bee colony algorithm applied to the bi-objective orienteering problem. Knowledge-Based Systems, 154, 93-101. https://doi.org/10.1016/j.knosys.2018.05.005

Masoomi, Z., Mesgari, M. S., \& Hamrah, M. (2012). Allocation of urban land uses by multi-objective particle swarm optimization algorithm. International Journal of Geographical Information Science, 27(3), 542-566. doi:10.1080/13658816..698016

Masoumi, Z., Maleki, J., Mesgari, M. S., \& Mansourian, A. (2017). Using an evolutionary algorithm in multiobjective geographic analysis for land use allocation and decision sup- 
porting. Geographical Analysis, 49(1), 58-83.

https://doi.org/10.1111/gean.12111

MathWorks. (2015). MATLAB and Statistics Toolbox Release 2012b. Natick, Massachusetts, United States.

Mosadeghi, R., Warnken, J., Tomlinson, R., \& Mirfenderesk, H. (2015). Comparison of Fuzzy-AHP and AHP in a spatial multi-criteria decision making model for urban land-use planning. Computers, Environment and Urban Systems, 49(2015), 54-65. https://doi.org/10.1016/j.compenvurbsys.2014.10.001

Murata, T., \& Ishibuchi, H. (1995, 29 November-1 December, 1995). MOGA: multi-objective genetic algorithms. Paper presented at the Proceedings of the 1995 IEEE international conference on evolutionary computation, Perth, WA, Australia.

Myers, G. A. (2008). Peri-urban land reform, political-economic reform, and urban political ecology in Zanzibar. Urban Geography, 29(3), 264-288.

https://doi.org/10.2747/0272-3638.29.3.264

Neema, M. N., \& Ohgai, A. (2010). Multi-objective location modelling of urban parks and open spaces: Continuous optimization. Computers Environment and Urban Systems, 34(5), 359376. https://doi.org/10.1016/j.compenvurbsys.2010.03.001

RGoZ. (2007). Zanzibar strategy for growth and reduction of poverty (ZSGRP). Zanzibar.

RGoZ. (2011). Revisited Zanzibar Development Vision 2020. Zanzibar.

Saadatseresht, M., Mansourian, A., \& Taleai, M. (2009). Evacuation planning using multiobjective evolutionary optimization approach. European Journal of Operational Research, 198(2009), 305-314. https://doi.org/10.1016/j.ejor.2008.07.032

Saaty, T. L. (1980). The analytic hierarchy process, planning, piority setting, resource allocation. New York: McGraw Hill.

Salim, I. S., \& Mwaipopo, L. J. (2016). What satisfies tourists in cultural heritage sites? Evidence of Zanzibar Stone Town. Journal of Research in Hospitality, Tourism and Culture, 3(1), 1-10.

Sharpley, R., \& Ussi, M. (2014). tourism and governance in Small Island Developing States (SIDS): The Case of Zanzibar. International Journal of Tourism Research, 16, 87-96. https://doi.org/10.1002/jtr.1904

Shaygan, M., Alimohammadi, A., Mansourian, A., Govara, Z. S., \& Kalami, S. M. (2014). Spatial Multi-Objective Optimization Approach for Land Use Allocation using NSGA-II. IEEE Journal of Selected Topics in Applied Earth Observations and Remote Sensing, 7(3), 906-916. https://doi.org/10.1109/JSTARS.2013.2280697

Shi, Y., \& Eberhart, R. C. (1998). A modified particle swarm optimizer. Paper presented at the Proceedings of IEEE International Conference on Evolutionary Computation. Piscataway, NJ. https://doi.org/10.1109/ICEC.1998.699146
Shifa, M., Jianhua, H. E., Feng, L. I. U., \& Yan, Y. U. (2011). Land-use spatial optimization based on PSO algorithm. GeoSpatial Information Science, 14(1), 54-61. https://doi.org/10.1007/s11806-011-0437-8

Sida. (2004). A future for the past: historic cities in development. Stockholm.

Silva, C. N. (2015). Urban planning in Sub-Saharan Africa: colonial and postcolonial planning cultures. New York: Routledge. https://doi.org/10.4324/9781315797311

Sjöstrand, J. (2014). Cultivating authenticity: Perceptions of Zanzibari culture and history within the heritage management of Stone Town (Master's Thesis in Urban and Regional Planning), Stockholm University, Stockholm.

Srinivas, N., \& Deb, K. (1994). Multi-objective optimization using non-dominated sorting in genetic algorithms. Evolutionary Computation, 2(3), 221-248. https://doi.org/10.1162/evco.1994.2.3.221

Stewart, T. J., Janssen, R., \& Van Herwijnen, M. (2004). A genetic algorithm approach to multiobjective landuse planning. Computers \& Operations Research, 31(2004), 2293-2313. https://doi.org/10.1016/S0305-0548(03)00188-6

Ullah, K. M., \& Mansourian, A. (2015). Evaluation of land suitability for urban land-use planning: case study Dhaka city. Transaction in GIS. https://doi.org/10.1111/tgis.12137

UN-Habitat. (2010). Planning sustainable cities: UN-habitat practices and perspectives. Nairobi.

UNESCO. (2000). Stone Town of Zanzibar. UNESCO.

Wang, \& Li, Y. (2015, 12-14 December). Multi-objective artificial bee colony algorithm. 2015 International Conference on Computational Intelligence and Communication Networks (CICN). Jabalpur, India: IEEE.

Wang, H., Shen, Q., Tang, B., \& Skitmore, M. (2013). An integrated approach to supporting land-use decisions in site redevelopment for urban renewal in Hong Kong. Habitat International, 38, 70-80. https://doi.org/10.1016/j.habitatint.2012.09.006

Xu, G., Yang, Y., Liu, B., Xu, Y., \& Wu, A. (2015). An efficient hybrid multi-objective particle swarm optimization with a multi-objective dichotomy line search. Journal of Computational and Applied Mathematics, 280(2015), 310-326. https://doi.org/10.1016/j.cam.2014.11.056

Yan, G., \& Li, C. (2011). An effective refinement artificial bee colony optimization algorithm based on chaotic search and application for PID control tuning. Journal of Computational Information Systems, 7, 3309-3316.

Zitzler, E., \& Thiele, L. (1999). Multiobjective evolutionary algorithms: A comparative case study and the strength Pareto Approach. IEEE Transactions on Evolutionary Computation, 3(4), 257-271. https://doi.org/10.1109/4235.797969 